\title{
THE RELATIONSHIP BETWEEN ISLAMIC FUNDAMENTALISM AND RADICALISM WITH SOCIAL CONFLICT
}

\author{
Deni Irawan and Zarul Arifin \\ Institut Agama Islam Sultan Muhammad Syafiuddin Sambas \\ email: deniirawan@gmail.com, zarularifin89@gmail.com
}

Abstract: Islamic fundamentalism has often been accused as a source of conflict so that it should be ended immediately. And the radical movement should put forward a complete understanding of diverse religions. Likewise, in every movement, it is necessary to keep the political and economic interests away from religion, because such factors triggers inter-religious conflict. The brutal act by a group of people who claims the most righteous by displaying the most sinister and frightening face of Islam, is really far from Islamic values. Islam is rahmatan lil 'alamin, especially towards fellow Muslims who believe in the truth of Islam based on the Koran and the Sunnah as the main and first source of Islamic teachings. If this motto is implemented seriously, the conflicts that have occurred will not be repeated. In its further development, fundamentalism undergoes a change, a shift, and is further away from its origin. The discussion of fundamentalism today is more associated with a negative impression that Islam is a religion of violence, anti-progress and establishment, conservative, antiWestern, and always takes violence to achieve its goals. This labeling and stigmatization of course has greatly marginalized Islam in international relations. This kind of stigmatization can be understood by Muslims so that they also hold counters in various ways, including counter discourse. However, the efforts made by Muslims have not been able to change the world view of Islam, especially the Western world. Islam to this day is still perceived as a violent religion.

الملخص: كما يتم التعبير عنها في كثير من الأحيان في شكل اتهامات ، بأن الأصولية الإسلامية

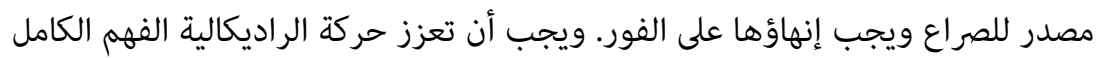




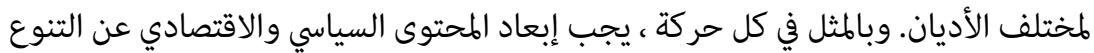

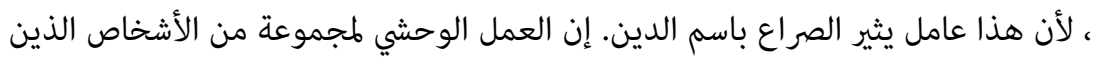

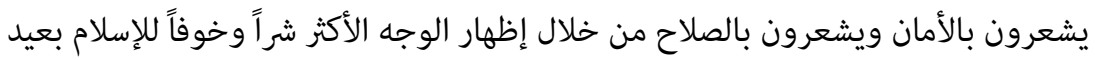

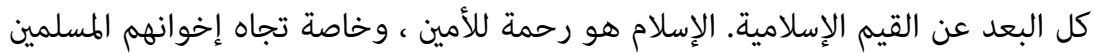

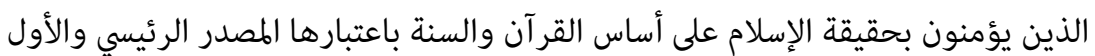

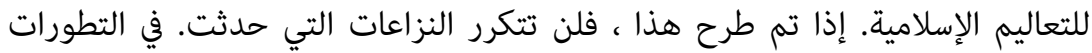

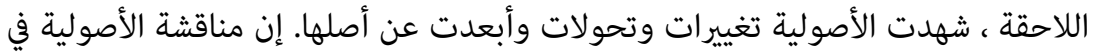

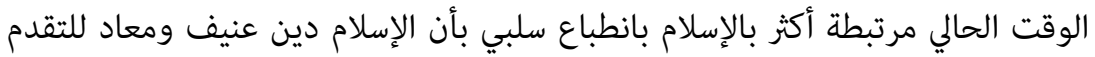

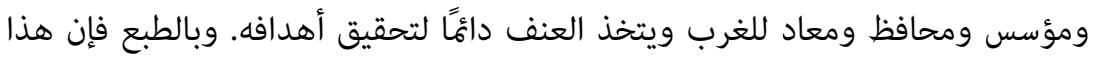

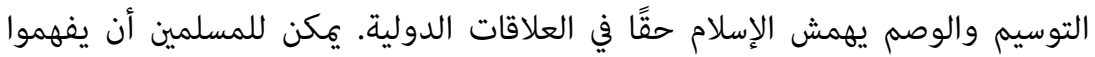

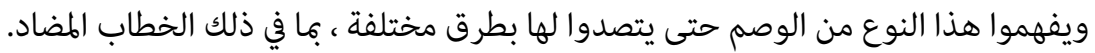

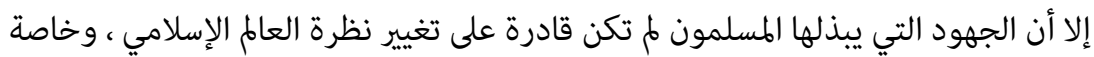

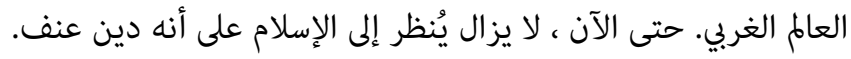

Abstrak: Seperti yang sering diungkapkan dalam bentuk tudingan, bahwa fundamentalisme Islam merupakan sumber konflik sehingga harus segera diakhiri. Dan gerakan radikalisme harus mengedepankan pemahaman yang utuh tentang beragam agama. Begitu pula dalam setiap gerakan, muatan politik dan ekonomi perlu dijauhkan dari keberagaman, karena inilah faktor yang memicu terjadinya konflik yang mengatasnamakan agama. Tindakan brutal sekelompok orang yang merasa paling aman dan merasa paling benar dengan menampilkan wajah Islam yang paling seram dan menakutkan, sungguh jauh dari nilai-nilai Islam. Islam adalah rahmatan lil alamin, terutama terhadap sesama umat Islam yang meyakini kebenaran Islam berdasarkan Alquran dan Sunnah sebagai sumber utama dan pertama ajaran Islam. Jika ini dikedepankan maka konflik yang telah terjadi tidak akan terulang kembali. Dalam perkembangan selanjutnya, fundamentalisme mengalami perubahan, pergeseran, dan semakin jauh dari asalnya. Pembahasan fundamentalisme saat ini lebih banyak dikaitkan dengan Islam dengan kesan negatif bahwa Islam adalah agama yang kekerasan, anti kemajuan dan kemapanan, konservatif, anti Barat, dan selalu mengambil kekerasan untuk mencapai tujuannya. Pelabelan dan stigmatisasi 
ini tentu saja sangat memarjinalkan Islam dalam hubungan internasional. Stigmatisasi semacam ini dapat dipahami dan dipahami oleh umat Islam sehingga mereka pun mengadakan tandingan dengan berbagai cara, termasuk tandingan wacana. Namun upaya yang dilakukan oleh umat Islam belum mampu mengubah pandangan dunia Islam, khususnya dunia Barat. Islam hingga saat ini masih dipersepsikan sebagai agama kekerasan.

Keyword: Islam, fundamentalism, radicalism, social conflict.

\section{INTRODUCTION}

Indonesian society is a plural society, both in national and regional scope with diverse culture, ethnicities, religions, races. Plurality is multidimensional in nature, some are caused by differences in ethnicities, social levels, political organizations, religions, and so on. Ideas for understanding the social system of a pluralistic society are in turn very important to foster national integration and to prevent disintegration and inter-group conflict, ${ }^{1}$

Throughout the history, diversity has resulted in a very beautiful combination in various forms of the cultural mosaic. Various ethnicities, religions, customs, and cultures can coexist and have a very high negotiation space in everyday life. However, these beautifully woven varieties are now torn and torn apart by an exclusive understanding that grows from the narrow primordial roots of ethnicity, religion, and social class. This resulted in conflicts or riots occurring in several regions. ${ }^{2}$ The occurrence of these conflicts is generally attributed to the failure in managing diversities, even though there are certain factors directly cause the conflicts.

The conflict is a product of the diversity of life philosophies and political ideologies that are popular in Western civilization and also the diversity of views about the ultimate values and goals of human life. For those who want to anticipate or perhaps want to

1 HM. Atho Mudzhar, Pendekatan Studi Islam Dalam Teori Dan Praktek (Yogyakarta: Pustaka Pelajar, 2002), 127.

2 Titik Suwartini, "Konflik-Konflik Sosial Bernuansa Agama Di Berbagai Komunitas (Kasus Kerusuhan Sosial Di Banjarmasin 1977)” Dalam Departemen Agama RI, Konflik Sosial Bernuansa Agama Di Indonesia (Jakarta: Badan Litbang dan Diklat Keagamaan, 2003), 1. 
understand the discussion about the conflict in Islamic jurisprudence based on the above understanding of the conflict, they will likely feel disappointed, but may also feel relieved. ${ }^{3}$ This disappointment and relief come from groups that embraced jihadism.

Today, religious life continues to be colored with acts of violence, radicalism, and especially the seeds of fundamentalism in practicing Islamic teachings. Undoubtedly, they do not stand alone; there is a reason that triggers a concerning thing to happen in social life. ${ }^{4}$ Violence and radicalization should not occur if they promote social interaction in the community.

According to M. Qasim Mathar, in this day and age, social contact and interaction between people from different backgrounds unavoidable, even the intensity is getting higher. This social interaction occurs due to, among other things, the similarity of professions, neighbors, daily activities, and others, or due to certain inequalities such as political, economic, cultural aspirations which, among other things, develop into conflicts with ethnic and religious nuances. ${ }^{5}$

What M. Qasim Mathar stated was a social reality faced by society today as a result of the leaps of the times which changes rapidly, but sometimes is not accompanied by an awareness of social change. This means that the times have changed so rapidly, but the people are not able to keep up with the changing times. As a result, many people are not ready to embrace diversity, especially in religions or theology. Such people consider other people to be wrong, heretical, and misleading and even considered infidel if they do not believe they believe in and practice what they do, even though the understanding that is considered heretical has bases that refer to the al-Qur' an and hadith. ${ }^{6}$

3 Noel J. Coulson, Konflik Dalam Yurisprudensi Islam, terj. H. Fuad (Yogyakarta: Navila, 2001), 1.

4 Hery Sucipto, "Memahami Fundamentalisme Islam Kontemporer," Dalam Hery Sucipto, ed, Islam Mazhab Tengah: Persembahan 70 Tahun Tarmizi Taher (Jakarta: Grafindo Khazanah, 2007), 33.

5 M. Qasim Mathar, "Kimiawi Pemikiran Islam, Arus Utama Islam Di Masa Depan" (Naskah Pidato Pengukuhan Guru Besar Filsafat Islam, Senin 12 Nopember 2007), 5 .

${ }^{6}$ Barsihannor, Haruskah Membenci Ahmadiyah (Yogyakarta: Kota Kembang, 2009), 2. 
Based on the background description above, the authors formulate the main problems; how the existence of Islamic fundamentalism and radicalism and its relationship with the occurrence of social conflicts in today's society.

\section{INTERNAL AND INTER-RELIGIOUS HARMONY}

Ideally, relations between religious communities are better and more harmonious, as well as internal religious communities so that harmony can be well established. The study of inter-religious and inter-ethnic relations now encounters new challenges and is increasingly interesting to research and discuss. This is due to the emergence of conflicts with the nuances of SARA (ethnic, Religion, Race, and Intergroup) and changes in social and religious dynamics that occur in the field.

In the last few years, the issue of religious violence has spread so quickly to various layers that it has created quite tense vulnerabilities in the religious life of the community. If certain issues arise, they will trigger very large and sometimes excessive reactions that tends to be violent, so that it has created a tense and disturbing atmosphere in life. ${ }^{7}$

The diversity of ethnicities, languages, customs, and religions is a fact that must be grateful as a national asset. However, pluralism and diversity can also contain vulnerabilities that can lead to conflicts of interest between different groups. ${ }^{8}$ Conflicts will not occur between groups if they realize the reality of diversity, because it already has a clear legal basis.

The term religious harmony has become a standard term in various laws and regulations in Indonesia. The formulation of religious harmony contains three elements:

1. Willingness to accept differences in beliefs among other people or groups;

2. Willingness to let others practice the teachings they believe;

7 Muhaimin, "Kata Pengantar" Dalam Departemen Agama RI, Konflik Sosial Bernuansa Agama Di Indonesia Seri II (Jakarta: Badan Litbang Agama dan Diklat Keagamaan Puslitbang Kehidupan Beragama Bagian Proyek Peningkatan Pengkajian Kerukunan Hidup Umat Beragama, 2003), iii.

8 Muh. Nahar Nahrawi, Kompilasi Peraturan Perundang-Undangan Kerukunan Hidup Umat Beragama Edisi Ke-9 (Jakarta: Puslitbang Kehidupan Keagamaan, 2007), 2. 
3. The ability to accept differences then enjoy the special atmosphere that other people feel when they practice their religious teachings.

The formulation of harmony above is basically an actualization of the nobility of each religious teaching that is adopted by everyone. More than that, every religion is a way of life for the welfare of mankind which comes from divine teachings. Officially the concept of religious harmony includes three harmony, namely, internal harmony of religious communities, harmony between people of different religions, and harmony between (leaders) of the religious community and the government. The three harmony is commonly referred to as "Tri Kerukunan". The terms used by the government were very closely related to the political interests during the Suharto era, so that political seeds emerged from various organizations such as fundamentalism and radicalism in various forms of their movements.

Even so, the exper i ence of dialogue between religious communities in everyday life is still better, compared to the attitudes of fanatics and ex clusivity who alienated themselves from other religious communit i es. If a person does not want to admit other religious beliefs, then what is true is his own belief. ${ }^{9}$ Dialogue between religious communities is important because it aims to: ${ }^{10}$ Examining the causes that le a d to disturbances in good relations between religious communities in Indonesia. Look for ways and means that will help promote peace in interfaith relations in Indonesia.

\section{ISLAMIC FUNDAMENTALISM AND RADICALISM}

\section{Fundamentalism.}

The term fundamentalism was not known in dictionaries of popular languages until the third millennium. Until 1996, this term did not exist in the Big Ruber's dictionary. Likewise the Encyclopedia Universalis, until 1968 it did not include this term. ${ }^{11}$

${ }^{9}$ Mun'im A. Sirry, Fiqih Lintas Agama: Membangun Masyarakat InklusifPluralis (Jakarta: Yayasan Wakaf Paramadina, 2004), 211.

${ }^{10}$ Harun Nasution. Islam Rasional: Gagasan Dan Pemikiran, Cet. V (Bandung: Mizan, 1998), 262.

${ }^{11}$ Roger Garaudy, Al-Ushuliyyat al-Mu'ashirah Asbabuha wa Muzahiruha, terjemah ke dalam Bahasa Arab oleh Khalil Ahmad Khalil (Paris: Dar' Am Alfain, 2000), 13. 
La Rose's Little Dictionary in 1969 provides a very general definition of the term fundamentalism, namely the attitude of those who reject the adjustment of the creed to new conditions. Meanwhile, the La Rose Pocket dictionary in 1979 devoted this term to mere Catholic teaching, namely the potential thinking possessed by some Catholics who do not like adjustments to new living conditions. In 1984, La Rose Besar appeared which gave a broader definition of fundamentalism (in volume 12), namely that in religious movements, (fundamentalism) is a total rejection to all forms of innovation. ${ }^{12}$

Roger Garaudy concludes some of the basic founders of fundamentalism, namely: first: statism (rejection of all forms of adjustment and development); second: return to the early generation of Muslims (turats affiliated, conservative); and third: intolerance (closed, school fanaticism). Thus, it can be said that fundamentalism positions itself as statism in the face of development; turats, in the face of modernity; fanaticism of the school in the face of neutralism. Or, in one word, fundamentalism can be called as the opposite of secularism. This plurality cannot be used as a basis for real fundamentalism.

In Arabic, the term fundamentalism is usually equated with the term ushuliyyah. The word ushuliyyah itself has actually been known long before the term fundamentalism appeared, for example in the terms ushul al-fiqh and ushul al-din. In this case, the word 'ashl (singular form of ushul) means the basis on which something is built: the basis of reason for the ulama ushul al-din and the basis of material (maslahat) for the ulama ushul al-fiqh. ${ }^{13}$

Ushuliyyah (fundamentalism) means returning to its origin, or returning to the Koran and the Sunnah. The term 'ushul' according to the understanding of some scholars means al-Quran and as-sunnah. Meanwhile, according to some scholars it means: the Koran and the Sunnah which was sahih. From this understanding, it can be said that the majority of Muslim believers can be classified as Ushuliyun (fundamentalists). They do not believe in violence and do not believe

12 John L. Esposito, Ensiklopedi Oxford: Dunia Islam Modern, Jilid 2 (Bandung: Mizan, 2002), 84.

${ }^{13}$ Hassan Hanafi, Al-Din wa al-Tsaurah fi Mishr, Vol. 6 (Kairo: Madbuli, 1952-1981), 6; Dikutip Dalam Hery Sucipto, "Memahami Fundamentalisme Islam Kontemporer," Dalam Hery Sucipto, ed, Islam Mazhab Tengah: Persembahan 70 Tahun Tarmizi Taher (Jakarta: Grafindo Khazanah Ilmu, 2007), 35. 
in terrorism, because both are against the Koran and as-sunna. ${ }^{14}$ Basically, fundamentalists do not agree with radical movements.

This is perhaps the reason some Muslim thinkers accept the term fundamentalism (usuliyyah) for the Islamic revival project (al-s (ahwah al-Islamiyyah) they are running. According to Hassan Hanafi, as the meaning contained in the terms ushul al-fiqh and ushul al-din, Islamic fundamentalism (al-usuliyyah al-islamiyyah) means an attempt to find a basis (principle) or legitimacy. Islamic fundamentalism, in one of its meanings, seeks to formulate this view and apply it: to develop Islamic system and defend it. Islamic revival must be fought for and applied in the Islamic system.

Therefore, according to Hassan Hanafi, Islamic fundamentalism does not necessarily mean conservatism, backwardness, and rejection of modern civilization. Some of the invaders were enlightened and forward-thinking; using modern revival methods and calling on the Muslims to develop science, technology, a democratic system and freedom. Islamic fundamentalism does not necessarily mean fanaticism, rejection of dialogue and isolation. Among the characters, there are those who think liberal, realistic, accept the challenges of the times and are open to modern civilization. One of the main agendas of various fundamentalist movements is to uphold Islamic law in Indonesia as an alternative by looking at the reality of the decline of Muslims, one of which is understood as a result of engineering by Jewish and Christian groups. ${ }^{15}$

Mahathir Mohamad stated that I am a fundamentalist Muslim, adhering to the fundamental principles of Islam, but that does not mean that Islam is incompatible with this era. Renewal among Muslims is not that difficult to understand that Islam is not only for the time of the Prophet Muhammad 1400 years ago. Islam will always be relevant for all ages. ${ }^{16}$ This means that fundamentalism

${ }^{14}$ Ali Syu'aibi dan Gils Kibil, Meluruskan Radikalisme Islam terj. Muhtarom, Cet. 2 (t.t.: Duta Aksara Mulia, 2010), 166-167.

15 "Pidato Sambutan Wakil Dari MUI Kota Malang Dalam Tabligh Akbar Mendukung Fatwa MUI, Tanggal 12 Agustus 2005, Sebagaimana Dikutip Oleh Umi Sumbullah, 'Gerakan Fundamentalisme Islam Di Malang: Studi Hizbut Tahrir, Majelis Mujahidin, Dan Arimatea' Dalam Departemen Agama RI, Jurnal Penelitian Islam Indonesia, Istiqra', 06, No. 01 (2007): 4-5.

${ }^{16}$ Mahathir Mohammad, "Menjadi Muslim Fundamentalis” Dalam Hery Sucipto, ed, Islam Mazhab Tengah: Persembahan 70 Tahun Tarmizi Taher (Jakarta: Grafindo Khazanah Ilmu, 2007), 381. 
does not agree if Muslims are struggling with backwardness, and want to progress and develop with modern civilization and even have advanced thoughts.

Many of them write about tolerance and cooperation, and call for brotherhood. Islamic fundamentalism does not necessarily mean exclusive groups, which use violence and acts of terror. Some of them are movements based on growing awareness of religion, state and politics, by using means of community reform such as religious education. And finally, Islamic fundamentalism does not necessarily mean adhering to symbolic identity, such as growing a beard, wearing the hijab, calling for the application of shari'ah and establishing an Islamic state. ${ }^{17}$

With regard to the emergence of fundamentalism in Islamic society in general, Garaudy agrees with Arkoun, namely making social, economic and political factors as causes, although Garaudy emphasizes more on factors originating from outside (external).

In general, the fundamentalists are usually divided into two parts: extreme and moderate. But if we examine it further, there is actually no such thing as a moderate fundamentalist. This can be seen from the terms they have developed, such as jahiliyyah, takfir and others, which prove that extremism and radicalism are the constant content of fundamentalism with all its currents. Fundamentalism being extreme cannot be separated from social, economic and political factors that cause the emergence of radical movements, especially Islamic radicalism. Assuming that Islamic fundamentalism is the mother of Islamic revivalist movements, this article seeks to discuss how the correlation between fundamentalist ideology and various ideological orientations of modern Islamic movements, such as puritanism and revivalism. $^{18}$

\section{Radicalism}

In Arabic, radicalism is usually called tatarruf, becoming mutatarrifin. Then, it is also interpreted by the term terror or creating disasters. Furthermore, it is explained that radicalism according to the big

${ }^{17}$ Azyumardi Azra, Islam Reformis: Dinamika Intelektual Dan Gerakan, Cet. 1 (Jakarta: Raja Grafindo Persada, 1999), 46-50.

${ }^{18}$ Afrohah, "Fundamentalisme: Korelasi Ideologi Fundamentalis Dengan Ideologi Gerakan Islam Modern.," Jurnal Tahrir Vol 18 No 1 Tahun 2018 (n.d.): 177. 
dictionary in Indonesian, the new initiative in 1995 is a school understanding that requires drastic change. (Big Indonesian dictionary of new ikhtiar: 1995). Meanwhile, according to the popular scientific dictionary, radicalism is the essence of change. (Bary, popular scientific dictionary: 1994) ${ }^{19}$ The emergence of radicalism in Islam is caused by: First, the factor of one's understanding of Islam and the abuse of Islam for individuals. This understanding is usually born because of acclusivism, they only justify their own group, so that they feel that they represent Islam and Islam is him. Second, lakum is punished by wa liyadin, which is interpreted as justification of Islam without acknowledgment of the existence of other religions. Though they should not follow them, but also not bother with them. ${ }^{20}$ Radical followers of their understanding of Islam lead to exclusivity and selfinterest, as well as subjective interpretations of the Koran.

The emergence of Islamic radical political groups was related to the establishment of the Ikhwan al-Muslimin party in the mid-early twentieth century. Its founders put forward the interpretation of the Koran subjectively to secure the political needs of the party towards the ladder of power. At first the party's establishment was closely related to the current of colonialism launched by Britain, the United States, and other western countries. Political Islamic thinkers, more or less, have committed a number of 'rapes' of the verses of the Koran by giving deviant and inappropriate interpretations. Deviation like this should not occur, because it has a negative impact on the ummah which results in a wrong understanding of the contents of the verse of the Koran.

This is what ultimately leads to religious radicalism, as happening to other religions. ${ }^{21}$ Furthermore, radical ideology was born from the notion of $\mathrm{jihad}^{22}$ as self and the idiom of war. This ideological

${ }^{19}$ Ahmad Asari, "RADIKALISME DI INDONESIA: Antara Historisitas Dan Antropisitas”, Jurnal Kalam Jurnal Studi Agama Dan Pemikiran Islam, Volume 9, Nomor 2, Desember $2015: 58$.

${ }^{20}$ Hasyim Muzadi, "NU, Radikalisme Ummatan Washato" Dalam Hery Sucipto, ed, Islam Mazhab Tengah: Persembahan 70 Tahun Tarmizi Taher (Jakarta: Grafindo Khazanah Ilmu, 2007), 341-342.

${ }^{21}$ S Yunanto, “Agama Dan Kekerasan Sebuah Catatan Politik Islam Indonesia”, Jurnal Multikultural Dan Multireligius Harmoni Vol. 6 No 1 Tahun 2003 (n.d.): 46.

${ }^{22}$ Alwi Shihab, "Keturunan Arab Dan Radikalisme Islam Indonesia” Dalam Hery Sucipto, ed, Islam Mazhab Tengah: Persembahan 70 Tahun Tarmizi Taher (Jakarta: Grafindo Khazanah Ilmu, 2007), 359. 
radicalism is then increasingly blurred, when non-religious interests are shared. Such political, economic, and even these interests are being fertilized again by too fast liberalization in Indonesia. This is what triggers violence that leads to social conflict, and has nothing to do with religion, as has happened in various regions.

Yusuf al-Qaradhawi said that the main factor in the emergence of radical attitudes was due to the inability to understand religious texts so that Islam was only understood superficially and partially.40 For example in QS. al-Baqarah: 208 as follows: "O you who believe, enter into the" religion of Islam "as a whole." This verse is often used as a justification for the concept of kaffah Islam with the formalization of an Islamic state and must be applied to its totality in the lives of Muslims so that the concept of Al-Islam Din wa Dawlah appears, Islam is a religion and a state. As an implication, the laws of human products, or state systems that are considered not based on Islam, are considered a taghut state. The occurrence of a misunderstanding of radicalism groups against Islamic law gave birth to radical attitudes and terro rism where there is a high enthusiasm for fighting for Islam, but lack of consideration, because of the lack of knowledge of Islamic law, understanding of the Koran and hadith in fragments, not comprehensive and far from the guidance of scholars who qualified in the knowledge of Islam. ${ }^{23}$

\section{CRITICAL REVIEW OF PRESENT-DAY SOCIAL CONFLICTS}

\section{Causes of Social Conflict}

Religion is often used as the most sensitive and exclusive point of contact in plural society. According to various studies conducted by various groups, it turns out that developments like this are not solely due to religious factors, but by various interrelated reasons, namely:

a. The crisis in various fields that occurred several years ago, in the end, in addition to creating a loss of public trust in the government apparatus (bureaucracy and military) which over the years had

${ }^{23}$ Syamsul Fatoni, "Pembaharuan Regulasi Terorisme Dalam Menangkal Radikalisme Dan Fundamentaslisme”, Jurnal Al-Tahrir Volume 18 N0. 1 Tahun 2018: 234. 
shown a lack of sympathy for some people, it also created high mutual suspicion among various people and community groups.

b. As a result of the first cause, religious propaganda has also developed which increasingly creates the exclusivity and sensitivity of group interests such as sermon forums, recitation, exclusive religious missions, and so on.

c. Social, economic and political disparities, which make it easier for religious followers to be dragged into the flow of competition, conflict and even hostility between groups.

These three thingsinclude the tension in relations between communities, and these three factors have their own dynamics. And if we observe closely the tensions of life that occur in some people, it seems that there has not been strong sense of optimism that the current harmony of the nation will soon be replaced with a bright atmosphere. This can be proven by the occurrence of social conflicts, among others; Banjarmasin, West Kalimantan, Mataram, Poso, Kupang, East Nusa Tenggara, Lampung, Ambon, Palangkaraya, and Kota Waringin Timur.

Most of the conflicts that occurred in the area had religious nuances, and the rest had religious nuances. And for the discussion in this paper the author chooses social conflicts as follows:

\section{a. Social unrest in Banjarmasin in 1997}

Based on the conclusions from the results of research conducted by Titik Suwariyati, about the occurrence of religious-nuanced social conflicts in various communities: cases of social unrest in Banjarmasin in 1997, namely:

1) The riot of 23 May 1997 or better known as "Jum'at Kelabu" was more dominant with political nuances. The riots were the escalation of the 1997 election campaign activities which were not under the control of the relevant OPP leadership. However, religious nuances cannot be ignored because of the use of religious symbols in the event, apart from that socio-economic factors also play a role.

2) The riot is a scenario created by certain parties. 
3) There was an attitude by some regional officials to close down the 23 May 1997 incident and did not want to bring it up again, especially with regard to religion.

Thus, the main trigger for the conflict in Banjarmasin was more dominant with political nuances, namely during the implementation of the 1997 election campaign. Besides, it also triggered social and economic factors, and religious factors, because the rioting used religious symbols.

\section{b. Social conflict in Poso}

The Poso conflict has been described as a three-act tragedy. The first rioting was on 25-30 December 1998, the second was on 1521 April 2000, and the third one was on 23 May - 10 June 2001. Based on the conclusions of the research conducted by Mursyid Ali, on religious social conflicts (a case study of the Poso riot tragedy ), namely: The Poso riot tragedy was a horizontal conflict between Muslim and Christian groups, and this conflict was not the main cause. The main triggers are very complex regarding various issues surrounding organization and power struggles, economic disparities, blunt security functions, relatively low effectiveness of government instruments, barren rule of law, displaced local cultural institutions. Reformation atmosphere and some of the mass media which tend to be wild, naughty, partisan and maybe excessive orientation. ${ }^{24}$

This conflict occurred due to factors surrounding power struggles and economic disparities which resulted in horizontal conflicts between Islam and Christianity.

\section{c. Social conflict in Ambon}

Social conflicts with religious nuances in the Ambon riot started from the attack on Wailete Hamlet (Muslim Buton) which was pelted with stones, and burned houses on December 13, 1998. The Air Bak incident, which was a Muslim citizen, was attacked, because a pig was driven from the garden of a Muslim resident on December 27, 1998 in Dobo (majority Christian), Tanibar, and Southeast Maluku, riots occurred on January 14, 1999. And, a big riot occurred in Ambon

${ }^{24}$ Mursyid Ali, Konflik Sosial Bernuansa Agama (Studi Kasus Tentang Tragedi Kerusuhan Poso) (Jakarta: Badan Litbang dan Diklat Keagamaan, 2003), 102. 
on January 19, 1999 to coincide with the Muslim holiday of Eid alFitr. $^{25}$

Based on the conclusion from the research results, the sociological condition underlying the conflict in Ambon is feeling increasingly pressed Christians politically, economically and demographically. Thus, the conflict in Ambon as described above dominates the political nuances.

\section{d. Conflict on Ahmadiyah}

The various social conflicts that have occurred so far have been motivated by religious sentiment and religious understanding. They declare war on groups deemed "deviant" and consider their movement an effort to maintain religious "purity". One of the victims of this movement is Ahmadiyah. After the Indonesian Ulema Council (MUI) issued a heretical fatwa against several religious groups, including the Ahmadiyah on July 29, 2005/22 Jumadil Akhir 1426 H., there were physical and psychological acts of violence against the Ahmadiyah congregation at the Al-Mubarak Parung Campus, Bogor. ${ }^{26}$

The factors behind the freezing support for the Ahmadiyah organization by community groups include: First, the existence of an MUI fatwa since 1980 stating Ahmadiyah as heretical, and strengthened by the MUI fatwa dated July 29, 2005, which reaffirms Ahmadiyah's deviance. Second, Ahmadiyah is considered to have deviated from the pure teachings of Islam.

Thus, the MUI fatwa triggered the attack on Ahmadiyah, this has led to a strong reaction from the NGO, JIL AMM, which stated that this act was outside the corridor of law and violated human rights.

\section{Critical Review of the Conflict}

Syafi'i Ma'arif expressed his disappointment at the brutal and arbitrary actions of a group of people who felt the most "Islamic" and felt the most righteous by displaying the face of Islam which is scary and hard in religion. This means that all actions taken by

${ }^{25}$ Sujangi, Konflik-Konflik Sosial Bernuansa Agama Studi Kasus Kerusuhan Ambon (Jakarta: Badan Litbang dan Diklat Keagamaan, 2003), 172-173.

${ }^{26}$ Lutfi Assyaukanie, Islam Benar Versus Islam Salah (Jakarta: Kata Kita, 2007), 163. 
certain groups of people get strong reactions from various circles, both Muslim and non-Islamic.

If we look closely at the occurrence of social, religious and religious conflicts as well as those related to ethnicity, race and between groups, most of them are caused by political factors. For example, the riots in Banjarmasin were the escalation of the 1997 election campaign activities which were not under the control of the relevant OPP leadership. Besides that, there are scenarios made by certain parties to carry out riots.

Likewise, the Poso riot tragedy which appeared to the surface, was a horizontal conflict between Muslim and Christian groups, even though this conflict was not the main cause. The main trigger is very complex concerning a variety of issues around organization and power struggles, and economic inequality,

The tragedy and riots in Ambon Maluku were triggered by the sociological conditions underlying the conflict in Ambon. Because of the feeling of increasing pressure on Christians in Ambon, who number over $50 \%$, both politically, economically and demographically.

The issuance of the MUI fatwa since 1980 stating Ahmadiyah as heretical, and reinforced by the MUI fatwa dated July 29, 2005, which reaffirms Ahmadiyah's heresy. This fatwa leads to the attack on Ahmadiyah in Parung Bogor. And it is possible that the attack had gone through certain scenarios, which aimed and gave the impression that Indonesia was often hit by riots.

So, all kinds of conflicts, riots, tragedies, and attacks on certain religious groups are heavily dominated by political factors. And this has nothing to do with Islamic fundamentalism, because it is a movement that aims to purify Islam. But it may be related to Islamic radicalism, which according to some people, that the trigger for conflict, especially in Indonesia, is due to the movement.

Because the emergence of Islamic radical groups was related to the establishment of the Ikhwan al-Muslimin party in the middle of the early twentieth cent ury. Its founders put forward the interpretation of the Koran subjectively according to the political needs of the party towards the ladder of power. 


\section{CONCLUSION}

Islamic fundamentalism is an Islamic movement that aims to purify Islam based on the Koran and the Sunnah. This movement is pursued and fought for so that Muslims are not out of date, and are able to color the development of modern times. Because the existence of fundamentalism is basically ushuliyyah which means returning to its origin, fundamentalism really does not condone violence and does not believe in terrorism. They are more directed towards the development of Islam to compete and take part in modern times of Indonesia. Therefore, fundamentalism has nothing to do with the social conflicts that have occurred so far. But fundamentalism has a charge of radicalism to struggle. This is mistaken for blaming others and justifying oneself. Moreover, their struggles are politically oriented radicals, so the existence of Islamic radicalism like this is the cause of social conflict in society.

The occurrence of social conflicts today is not caused by differences in understanding of religion internally or externally. But there is more political, economic and demographic factors. This is evidence from social conflict in regions such as; Banjarmasin, Poso, Ambon and cases related to the violation of Ahmadiyah teachings. Especially for Ahmadiyah, the trigger is the MUI fatwa which states that Ahamadiyah is heretical. And another factor that triggers it is the political factor that dominates a lot, because it is closely related to the government's interests.

\section{REFERENCES}

Afrohah. "Fundamentalisme: Korelasi Ideologi Fundamentalis Dengan Ideologi Gerakan Islam Modern.” Jurnal Al-Tahrir Vol 18 No 1 Tahun 2018 (n.d.): 177.

Ahmad Asari. "RADIKALISME DI INDONESIA: Antara Historisitas Dan Antropisitas', Jurnal Kalam Jurnal Studi Agama Dan Pemikiran Islam, Volume 9, Nomor 2, Desember 2015, 258.

Ali Syu'aibi dan Gils Kibil. Meluruskan Radikalisme Islam Terj. Muhtarom, Cet. 2; t.t.: Duta Aksara Mulia, 2010. 
Alwi Shihab. "Keturunan Arab Dan Radikalisme Islam Indonesia" Dalam Hery Sucipto (ed.), Islam Mazhab Tengah: Persembahan 70 Tahun Tarmizi Taher. Jakarta: Grafindo Khazanah Ilmu, 2007.

Azyumardi Azra. Islam Reformis: Dinamika Intelektual Dan Gerakan, Cet. 1, Jakarta: Raja Grafindo Persada, 1999.

Barsihannor. Haruskah Membenci Ahmadiyah, Cet. 1. Yogyakarta: Kota Kembang, 2009.

Harun Nasution. Islam Rasional: Gagasan Dan Pemikiran. Cet. VBandung: Mizan, 1998.

Hassan Hanafi. Al-Din wa al-Tsaurah fi Mishr, Vol. 6, Kairo: Madbuli, 1952-1981), dalam Hery Sucipto, "Memahami Fundamentalisme Islam Kontemporer," Dalam Hery Sucipto, (ed.), Islam Mazhab Tengah: Persembahan 70 Tahun Tarmizi Taher. Jakarta: Grafindo Khazanah Ilmu, 2007.

Hasyim Muzadi. "NU, Radikalisme Ummatan Washato" Dalam Hery Sucipto, (ed.), Islam Mazhab Tengah: Persembahan 70 Tahun Tarmizi Taher. Jakarta: Grafindo Khazanah Ilmu, 2007.

Hery Sucipto. "Memahami Fundamentalisme Islam Kontemporer," Dalam Hery Sucipto,(ed.), Islam Mazhab Tengah: Persembahan 70 Tahun Tarmizi Taher. Jakarta: Grafindo Khazanah, 2007.

HM. Atho Mudzhar. Pendekatan Studi Islam Dalam Teori Dan Praktek. Yogyakarta: Pustaka Pelajar, 2002.

John L. Esposito. Ensiklopedi Oxford: Dunia Islam Modern Jilid 2. Bandung: Mizan, 2002.

Lutfi Assyaukanie. Islam Benar Versus Islam Salah. Jakarta: Kata Kita, 2007.

M. Qasim Mathar. Kimiawi Pemikiran Islam, Arus Utama Islam Di Masa Depan (Naskah Pidato Pengukuhan Guru Besar Filsafat Islam, Senin 12 Nopember 2007), Dikutip Dalam Barsihannor, Haruskah Membenci Ahmadiyah. Yogyakarta, 2009.

Mahathir Mohammad. "Menjadi Muslim Fundamentalis”, Dalam Hery Sucipto (ed.), Islam Mazhab Tengah: Persembahan 70 
Tahun Tarmizi Taher, Cet. 1, Jakarta: Grafindo Khazanah Ilmu, 2007.

Muh. Nahar Nahrawi. Kompilasi Peraturan Perundang-Undangan Kerukunan Hidup Umat Beragama Edisi Ke-9. Jakarta: Puslitbang Kehidupan Keagamaan, 2007.

Muhaimin. "Kata Pengantar" Dalam Konflik Sosial Bernuansa Agama Di Indonesia Seri II. Jakarta: Badan Litbang Agama dan Diklat Keagamaan Puslitbang Kehidupan Beragama Bagian Proyek Peningkatan Pengkajian Kerukunan Hidup Umat Beragama, 2003.

Mun'im A. Sirry (ed.), Fiqih Lintas Agama: Membangun Masyarakat Inklusif-Pluralis. Jakarta: Yayasan Wakaf Paramadina, 2004.

Mursyid Ali. "Konflik Sosial Bernuansa Agama (Studi Kasus Tentang Tragedi Kerusuhan Poso" dalam Konflik Sosial Bernuansa Agama Di Indonesia. Jakarta: Badan Litbang dan Diklat Keagamaan, 2003.

Noel J. Coulson. Konflik Dalam Yurisprudensi Islam, terj. H. Fuad, Yogyakarta: Navila, 2001.

"Pidato Sambutan Wakil Dari MUI Kota Malang Dalam Tabligh Akbar Mendukung Fatwa MUI, Tanggal 12 Agustus 2005, Sebagaimana Dikutip oleh Umi Sumbullah, 'Gerakan Fundamentalisme Islam Di Malang: Studi Hizbut Tahrir, Majelis Mujahidin, Dan Arimatea' dalam Departemen Agama RI, Jurnal Penelitian Islam Indonesia, Istiqra', 06, No. 01 (2007)

Roger Garaudy. Al-Ushuliyyat al-Mu'ashirah Asbabuha Wa Muzahiruha, terjemah ke dalam Bahasa Arab oleh Khalil Ahmad Khalil. Paris: Dar' Am Alfain, 2000.

S Yunanto. "Agama Dan Kekerasan Sebuah Catatan Politik Islam Indonesia," Jurnal Multikultural Dan Multireligius Harmoni, Vol. 6 No 1 Tahun 2003.

Sujangi. "Konflik-Konflik Sosial Bernuansa Agama Studi Kasus Kerusuhan Ambon", Dalam Departemen Agama RI, Konflik Sosial Bernuansa Agama Di Indonesia. Jakarta: Badan Litbang dan Diklat Keagamaan, 2003. 
Syamsul Fatoni. "Pembaharuan Regulasi Terorisme Dalam Menangkal Radikalisme Dan Fundamentaslisme", Jurnal alTahrir, Volume 18 No. 1 Tahun 2018.

Titik Suwartini. "Konflik-Konflik Sosial Bernuansa Agama Di Berbagai Komunitas (Kasus Kerusuhan Sosial Di Banjarmasin 1977)", dalam Konflik Sosial Bernuansa Agama Di Indonesia. Jakarta: Badan Litbang dan Diklat Keagamaan, 2003. 